УДК 7.072 .2

DOI:

Тетяна Білан, кандидат філософських наук, доцент кафедри культурології та мистецької освіти

Дрогобииького державного педагогічного університету імені Івана Франка

\title{
МИСТЕЦТВО ЯК ЧИННИК ТВОРЧО-ОСОБИСТІСНОЇ СПРЯМОВАНОСТІ ОСВІТИ
}

У статті аналізуються чинники впливу освіти на розвиток духовної культури особистості та висвітлюються особливості філософсько-педагогічного осмислення ролі мистецтва в освітньому просторі. Доведено, шуо мистецтво виступає основою розвитку творчої індивідуальності за умови його залучення до творчої взаємодії з ним на засадах педагогіки мистеитвва, щзо поєднує в собі усі його педагогічні функції й репрезентує невичерпність педагогічного і творчого потенціалу мистецтва. Констатовано, цио посилення уваги до культуротворчого й креативного потенціалу освіти спричинює зміну соціокультурного статусу мистецтва, тим самим зумовлює набуття мистецтвом ролі важливого чинника забезпечення творчої та індивідуально-особистісної спрямованості освіти й перетворення мистецтва на важливий компонент змісту освіти.

Ключові слова: мистецтво; освіта; педагогіка мистецтва; художнє пізнання; культура; культуротворчість; творча особистість; художня культура.

תim. 9.

Tetyana Bilan, Ph.D.(Philosophy), Associate Professor of the Cultural Studies and Art Education Department Drohobych Ivan Franko State Pedagogical University

\begin{abstract}
ART AS A FACTOR OFTHE CREATIVE AND PERSONAL ORIENTATION OF EDUCATION
The article analyzes the factors of the influence of education on the development of the spiritual culture of the individual and highlights the peculiarities of philosophical and pedagogical comprehension of the role of art in the educational space. It is emphasized that one of the most important cognitive facets of art is the process of functioning of an artistic work in a society, which, appealing to human feelings, forms the possibility of a holistic world perception. It is noted that the process of cognitive activity is no longer a formal-logical alienation from the essence of man, but makes cognitive activity a particular component of the formation of harmonious reality, which implies the presence of semantic-value dialogue between man and the world. It is stressed that the characteristic features of the culture of modern Ukraine are changes in value orientations and spiritual directions, improvement of the system of education, its orientation towards integration into the international educational system. It is stated that the increased attention to the cultural-creative and purely creative potential of education leads to a change in the socio-cultural status of art, which, subsequently, leads to the acquisition of art as an important factor of ensuring the creative and individual-personal orientation of education and the transformation of art into an important component of the content of education, which gives educational entities a unique opportunity to experience and at the same time comprehend and appreciate the social and pedagogical experience and, through this, acquire the universal self-determination, inaccessible intelligence by means of them. Art develops the ability of the individual to inspire, expands the possibilities of human knowledge, makes a person capable for the most complete knowledge of the world and of himself, creates in a person the idea of the aesthetic peculiarity of social life, his aesthetic perfection. Art forms the basis of the development of creative individuality, provided that it is involved in creative interaction with him on the principles of art pedagogy, which combines all of pedagogical functions and represents the inexhaustibility of the pedagogical and creative potential of art.
\end{abstract}

Keywords: an art; an education; the pedagogy of art; artistic knowledge; a culture; cultural creativity; creative personality; an artistic culture.

$\Pi$ остановка й обгрунтування актуальності проблеми. Поширення впливу освіти на розвиток духовної культури особистості має стати пріоритетним завданням в сьогоденні, а висвітлення проблеми людини крізь призму філософії освіти та філософії мистецтва нині $є$ об'єктом філософськопедагогічних роздумів в контексті усвідомлення духовно-культурного буття суспільства. Однією з нагальних потреб сучасного освітнього простору $\epsilon$ заглиблення в неогуманістичні концепції, характерним для яких $\epsilon$ аналіз процесу становлення особистості не як спрямованого ззовні потоку стимулів-подразників, а як ii самопізнання, самовираження і самореалізація, що відбувається у певних життєвих ситуаціях існування людини у світі. Як зазначає О.М. Отич, "сучасна освіта може й повинна активно протидіяти суспільно-культурному регресу i сприяти загальному, художньо-естетичному, 
професійному й творчому розвиткові особистості, залучаючи молодь до культурно-мистецької діяльності з опанування вічних, перевірених часом загальнолюдських і національних гуманістичних цінностей, закладених у світовій та національній культурно-мистецькій спадщині й втілених у специфічний спосіб урізних видах мистецтва" [4,404].

Аналіз основних досліджень і публікацій. Загальнотеоретичні та методологічні підходи щодо використання мистецтва як чинника творчоособистісної спрямованості освіти завжди були предметом багатьох науковців i, зокрема, висвітлені у дослідженнях: О.М. Отич [4], О.П. Поліщук [6], О.П. Рудницької [7], В.Г. Скотного [8] та ін. В сьогоденні вплив мистецтва на формування особистості розглядається вченими, так, О. Поліщук, спираючись на естетико-культурологічний аналіз стимулів творчості, розкриває нове розуміння творчої особистості, окреслює значущість естетичних чинників "як вроджених, так і набутих, а головними елементами такої творчої натури виступають передусім високий рівень її сенсорної відкритості через здатність розширено сприймати реальність; іноді підвищена емоційність; специфічність мотиваційних настанов, а саме прагнення до самоствердження і самовдосконалення" $[6,168]$. Як зазначає О. Отич “квінтесенцією естетичних уявлень про індивідуальність є художня культура, в якій індивідуальність виступає як сутнісна властивість кожного 3 їі структурних елементів i репрезентується в якостях: по-перше, індивідуальності художника як системі модусів його творчості (від ремесла, майстерності, до мистецтва); по-друге, об'єктивації цієї індивідуальності в художніх та нехудожніх феноменах (видах, жанрах та стилях мистецтва, авторстві й поведінці тощо); по-третє, в індивідуальності як властивості твору мистецтва, що характеризує його як значущу одиницю культури, проявляється на різних рівнях (матеріальному, семантичному, духовному) та об'єктивується в межах твору, його імені, а також у його здатності до діалогічної взаємодії 3 реципієнтом; по-четверте, в індивідуальності глядача (слухача, читача) як характеристиці його духовного світу, естетичного й художнього досвіду, його діяльності в модусах власне сприймання, конкретизації-інтерпретації, асоціації та уяви, продуктивна сила якої реалізує зв'язок мистецтва 3 життєвим досвідом людини й об'єктивується в конкретній особистості” $[4,400]$. Як підкреслював В. Скотний культура, мистецтво “пристосовує людину до певного природного та соціального середовища, сприяє іiі соціалізації, виступає універсальним фактором саморозвитку індивіда, суспільства... та синтезує в цілісну і завершену форму систему чинників духовного світу особи пізнавальних, емоційно-чугтєвих, вольових" [8, 433].

Мета статті. 3' ясування теоретичної сутності ролі мистецтва як чинника творчо-особистісної спрямованості освіти та культуротворчого й креативного іiі потенціалу крізь призму проблем філософії освіти та мистецтва.

Виклад основного матеріалу. Основою художнього пізнання $є$ художньо-образна мова мистецтва, а однією 3 найважливіших пізнавальних граней мистецтва $\epsilon$ процес функціонування мистецького твору в суспільстві, що апелюючи до людських почуттів, формує можливості цілісного світосприйняття та спонукає до дискусії про взаємозв'язок художнього тексту 3 іншими текстами, як такими, що вже існували, так і сучасними йому текстами. Саме це призводить до взаємодії сучасних новостворених текстів з реципієнтом та соціокультурним середовищем, адже "художнє пізнання має певну специфіку, сутність якої полягає у цілісному відображенні світу й особливій позиції людини у світі. Художній твір будується на образі, а не на понятті. Сприйняття художнього образу передбачає розширення людського досвіду, який охоплює і сферу минулого і сучасного та сферу майбутнього. Життєвий досвід у його художній формі не лише збагачує людину баченням іншого життя, пізнанням раніше невідомого, але й сприйняттям складних почуттів, світу душевних переживань, моральних та інших проблем. Цей досвід - пізнавальний, емоційний та етичний створює зв'язок поколінь у загальному потоці всесвітньої історії $[8,263]$. Процес пізнавальної діяльності постає вже не формально-логічним відчуженням від сутності людини, а робить пізнавальну діяльність своєрідною складовою формування гармонійної дійсності, що передбачає присутність смислово-ціннісного діалогу людини і світу. Саме тому, слушним бути використати при осмисленні творів мистецтва своєрідну гносеологічну формулу: пізнання - чуттєве пізнання (відчуття, сприйняття, уявлення) раціональне пізнання (форма понять, суджень та умовиводів) - наукове пізнання (має творчий характер, бо містить інтуїцію, здогад, видумку) - життєве пізнання (спостереження, кмітливість) - художнє пізнання (художній образ), загальновідомо, що в “естетиці й мистецтвознавстві категорія індивідуальності пов'язується із неповторною своєрідністю особистості митця, особливою формою його буття і діяльності, що надає унікального характеру їх результатам” [4, 400]. 


\section{МИСТЕЦТВОЯК ЧИННИК ТВОРЧО-ОСОБИСТІСНОЇСПРЯМОВАНОСТІОСВІТИ}

За жодних обставин освіта не зможе замінити собою науку, сенсом якої є здобування об'єктивно нового знання, “поняття освіти дає змогу якнайвиразніше збагнути, наскільки глибокою $є$ духовна еволюція" [2, 18]. В цьому контексті актуальною $\epsilon$ проблема філософськопедагогічного осмислення ролі мистецтва в освітньому просторі, а мистецтво, як відомо, розвиває здібність особистості до натхнення, розширює можливості людського пізнання, розкриває силу та плідність духовного збагачення особистості. 3'єднуючи емоційне сприйняття 3 інтелектуальним, воно робить людинуздатною до найповнішого пізнання світу та самої себе, витворює у людини уявлення про естетичну своєрідність суспільного життя, його естетичну досконалість, сприяє розумінню естетичного ідеалу. Мистецтво виступає чинником творчоособистісної спрямованості освіти, зокрема сприяє формуванню творчої індивідуальності при цьому завжди варто опиратися на засади педагогіки мистецтва, адже вона репрезентує педагогічні функції мистецтва та 3'єднує воєдино педагогічну і творчу сутність мистецтва. Мистецтво також має здатність бути і засобом навчання та формування особистості, доповнювати компоненти освітнього процесу, зокрема стати чинником індивідуалізації особистості. В свою чергу культура здійснює активний вплив на людей, на їхнє життєствердження та діяльність “люди не лише створюють культуру під час під час матеріальної та духовної діяльності, але й оволодівають набутими знаннями, тобто зайняті засвоєнням культури. Будь-яка діяльність - практична чи теоретична, матеріальна чи духовна, поряд із творчим аспектом включає аспект функціонування - засвоєння культури" [8, 435]. Нині бачимо посилення уваги до культуротворчої складової освіти, і це дозволяє мистецтву стати важливим чинником індивідуально-особистісної спрямованості освіти, що надає суб'єктам освітнього процесу можливість переосмислити культуротворчий та педагогічний досвід, i дозволяє вести мову про формування культурознавчої компетентності. Наприклад, предметом вивчення навчальної дисципліни “Історія театру” $є$ висвітлення феномену театрального мистецтва як об’ єкта культурознавства та предмету дослідження історії театру: широке коло проблем, пов'язаних 3 “убудованістю” функціонування театру як специфічної соціокультурної системи в соціум (театр в системі суспільства та культури, суб'єкти театральної діяльності). Дисципліна “Історія театру” передбачає інтегроване вивчення історії театру як синтетичного виду мистецтва та поетапне засвоєння особливостей театрального мистецтва кожної окремо взятої культурно-історичної епохи у Європі, в Україні, з метою з'ясування іiї національної самобутності при безпосередньому порівнянні; розкриває розвиток та еволюцію театрального мистецтва як художньої картини світу, адже "значущість мистецтва засновується також на тому, про що воно нам говорить, показуючи людині їі ж саму в їі морально визначеному існуванні” $[2,56]$. Кожен вид мистецтва, з одного боку, спрямований на максимальне виявлення, посилення специфічних і неповторних художньо-мовних особливостей, 3 іншого - всі вони намагаються враховувати і використовувати досвід інших мистецтв, щоб розширити власні межі та можливості. Особливого значення розгляд інтертекстуальності театрального мистецтва набуває сьогодні, коли екзистенційне філософування відновлює свій розвиток, виступаючи продуктом інтеграції мистецького і філософського мислення, а взаємодія текстів у театральному мистецтві доводить єдність розуміння тексту із саморозумінням його інтерпретатора, що детермінує розуміння цілого тексту або його частин у процесі саморозуміння $[1,31]$. Так, наприклад, філософсько-освітній дискурс театрального мистецтва обумовлений не тільки своїм гуманістичним спрямуванням, а й здатністю переосмислити історично обумовлену істину. Слушною з цього приводу є думка німецького філософа Г.-Г. Гадамера щодо розуміння і тлумачення текстів та феноменів культури “той факт, що у творі мистецтва осягається істина, якої годі добути всіма іншими шляхами, і становить філософське значення мистецтва, що утверджує себе всупереч будьякому резонерству. Таким чином досвід мистецтва виявляється, поруч і з досвідом філософії, найнастійнішою засторогою науковій свідомості, аби вона визнавала свої власні кордони" $[2,8]$.

Сучасні дослідники мистецтва визнають головною відмінністю української культурної ситуації від зарубіжної те, що постмодерністська тенденція в країні виявилась із відчутним запізненням. Перетворювальні процеси початку 1990-х років, на думку А. Оленської-Петришин, створили ситуацію, в якій митцям було важко визначитися 3 художніми вартостями “нового суспільства” [3]. У зв’язку з цими процесами для сучасного мистецтва характерна велика кількість творчих напрямів, технологічних прийомів і 
засобів вираження, адже "протягом усього періоду виникнення i розвитку мистецтва, його наповнення сутнісним змістом важливими були три чинники - епоха з їі культурно-історичними особливостями, митець та реципієнт" $[5,14]$. “Сучасне" розуміємо як мистецтво періоду державної незалежності України, хоч вектори руху “сучасного мистецтва" складно визначити, проте епоха настання "постмодернізму” диктує свої правила, основним постулатом яких є визнання всіх мистецьких явищ рівноцінними.

Опираючись на естетико-культурологічний аналіз стимулів творчості, О.П. Поліщук зазначає, що “естетичне сприйняття світу виступає особливою активністю особистості, що не зводиться до простого розпізнавання його елементів при формуванні перцептивних моделей. Тут відбувається поглиблене набування інформації про елементи дійсності при паралельному їх оцінюванні (хоча б на рівні емоційно-почуттєвих реагувань" [6, 167]. У цих словах чітко прослідковується прагнення спонукати суб'єкта сучасного освітнього процесу до естетичного сприйняття світу крізь призму мистецтва. Саме тому, варто зазначити, що сучасне українське мистецтво сформувалося в 1960 - 70-х роках XX століття, це був непростий час для становлення національного мистецтва, але тогочасні художні тенденції можна вважати пошуком альтернатив модернізму, де відбувалося становлення i одночасно пошук нових образів і художньообразної мови мистецтва. У роки незалежності Україна проходить тернистий шлях створення різних умов задля збереження й розвитку своєї культури, духовних надбань українського народу, його кращих традицій і новацій. І вже сьогодні ми зрештою маємо певну інфраструктуру культури, яка робить можливим подальший духовний прогрес народу, використання для цього духовної скарбниці, витвореноїнашими пращурами [9, 444]. Зміни, викликані новою політикою державного суверенітету України, сприяли пожвавленню всіх стилів і манери зображення в малярстві. Стало очевидним, що незважаючи на штучну уніфікацію мистецтва, що придушувала природний розвиток живопису, українське малярство зберегло цілісність зв'язків 3 власною культурною спадщиною та західним мистецтвом і стверджує національну самобутність у поєднанні зі світовим мистецьким досвідом [7, 75]. У культурології та мистецтвознавстві кінець ХХ століття прийнято називати постмодернізмом. Таким чином, наприкінці XX століття настала доба постмодернізму, а сам термін "постмодернізм", трактуємо як тлумачення, історії виникнення, розвитку та відношення до попереднього модерністського етапу. Сучасне мистецтво спонукає до творчих пошуків завдяки художньообразній мові та засобів виразності, цікавими $є$ художні інновації, а саме: перфоменс, як мистецтво в дії, реаліті-шоу, флукус. Однозначного трактування характеристик та хронології постмодернізму немає, і саме різноманітні точки зору і визначають головну відмінність постмодернізму від попередніх етапів.

Висновки. Характерними рисами культури сучасної України є зміни ціннісних орієнтирів і духовних спрямувань, переосмислення власної історії, утвердження національної ідентичності, відновлення значущості релігійного життя та його активізація, вдосконалення системи освіти, спрямування іiï на інтеграцію в міжнародну освітню систему, розвиток усіх основних галузей і напрямків науки, культурна глобалізація.

Враховуючи сказане вище про мистецтво як чинник творчо-особистісної спрямованості освіти, можна констатувати, що мистецтво формує культуротворчий i креативний потенціал освітнього простору, і саме тоді процес пізнавальної діяльності постане вже не формально-логічним, а набуде рис смисловоціннісного діалогу людини зі світом, а це в свою чергу дозволить мистецтву стати чинником забезпечення творчої та інидвідуальноособистісної спрямованості освіти та важливим iї компонентом.

\section{ЛІТЕРАТУРА}

1. Білан Т. Інтертекстуальні рефлексії театрального мистецтва / Т.Білан // Вісник Львівського університету. Серія мистецтвознавство. - 2016. - Випуск 17. - С.30-36.

2. Гадамер Г.-Г. Істина і метод. Основи філософської герменевтики / Переклад з німецької Олександра Мокровольського: У 2 томах. / Г.-Г. Гадамер. - К.: "Юніверс", 2000. - Т.1. - 258 с.

3. Новоженець Г. Образотворче мистецтво української діаспори 1940-1970 років: поліваріантість художнього досвіду. - Львів: Кальварія, 2015. - 280 с.

4. Отич О. М. Мистецтво у розвитку індивідуальності педагога: історичний і методологічний аспекти: монографія / за наук. ред. I. А. Зязюна / О.М.Отич. - Чернівці: Зелена Буковина, 2008. - 455 с.

5. Петрів О. Ідейно-художні засади українського мистецтва початку XX століття / О. Петрів // Вісник Львівського університету. Серія мистецтвознавство. - 2016. - Випуск 17. - С.916. 
6. Поліщук О. П. Художнє мислення: естетикокультурологічний дискурс / О. П. Поліщук / Монографія. - К.: Видавець ПАРАПАН, 2007. $208 \mathrm{c}$.

7. Рудницька О. П. Українське мистецтво у полікультурному просторі: Навчальний посібник. - К.: "ЕксОб", 2000. - 208 с.

8. Скотний В. Г. Філософія: історичний i систематичний курс / В.Г.Скотний. - К.: Знання України, 2005. - 576 с.

9. Шейко В. М., Богуцький Ю. П. Формування основ культурології в добу цивілізаційної глобалізації (друга половина XIX - початок XXI ст.). Монографія. - К.: Генеза, 2005. - 592 с.

\section{REFERENCES}

1. Bilan, T. O. (2016). Intertekstualni refleksii teatralnoho mystetstva [Intertextual reflections of theatrical art]. Lviv University Herald. Series of art studies. Vol. 17, pp.30-36. [in Ukrainian].

2. Gadamer, H.-G. (2000). Istyna $i$ metod. Osnovy filosofskoi hermenevtyky [Truth and method. Fundamentals of philosophical hermeneutics]. Translation from German by Olexander Mokrovolskuj: in 2 volumes. Kyiv: "Iunivers", vol.1, 258 p. [in Ukrainian].

3. Novozhenets, H. (2015). Obrazotvorche mystetstvo ukrainskoi diaspory 1940-1970 rokiv: polivariantist khudozhnoho dosvidu [Fine arts of the Ukrainian diaspora from 1940-1970: multivariate art experience]. Lviv: Kalvariia, 280 p. [in Ukrainian].
4. Otych, O. M. (2008). Mystetstvo u rozvytku indyvidualnosti pedahoha: istorychnyi $i$ metodolohichnyi aspekty [Art in the development of the individual's personality: historical and methodological aspects]. Monohraf(Ed.). I. A. Ziaziun. Chernivtsi: Zelena Bukovyna, 455 p. [in Ukrainian].

5. Petriv, O. Ideino-khudozhni zasady ukrainskoho mystetstva pochatku KhKh stolittia [The ideological and artistic bases of the Ukrainian art of the early XX century]. Lviv University Herald. Series of art studies. Vol. 17, pp.9-16. [in Ukrainian].

6. Polishchuk, O. P. (2007). Khudozhnie myslennia: estetyko-kulturolohichnyi dyskurs [Artistic thinking: aesthetic-culturological discourse]. Monohraf. Kyiv: Vydavets PARAPAN, 208 p. [in Ukrainian].

7. Rudnytska, O. P. (2000). Ukrainske mystetstvo u polikulturnomu prostori: Navchalnyi posibnyk [Ukrainian art in the multicultural space]. Kyiv: "EksOb", 208p. [in Ukrainian].

8. Skotnyi, V. H. (2005). Filosofiia: istorychnyi $i$ systematychnyi kurs [Philosophy: a historical and systematic course]. Kyiv: Znannia Ukrainy, 576 p. [in Ukrainian].

9. Sheiko, V.M. \& Bohutskyi, Yu.P. (2005). Formuvannia osnov kulturolohii $v$ dobu tsyvilizatsiinoi hlobalizatsii (druha polovyna XIX - pochatok XXI st.) [Formation of the foundations of cultural studies in the era of civilizational globalization (the second half of the XIX - early XXI century)]. Monohraf. Kyiv: Heneza, 592 p. [in Ukrainian].

Стаття надійшла до редакції 23.07.2018

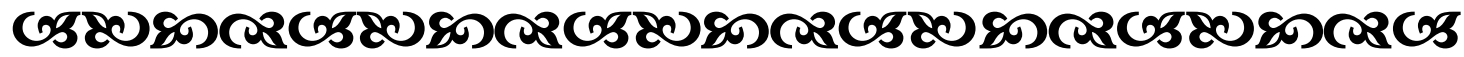

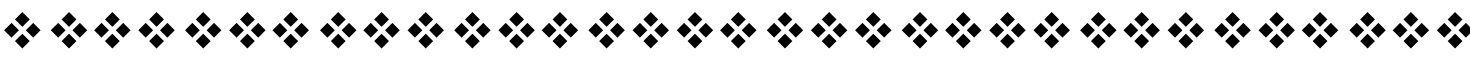

"Iiла історія нашої цивілізації, матеріальної і духовної, се не що інше, якпоступове систематичне і ненастанне відсування, відалювання границь неможливого”.

Іван Франқо

видатний уқраїнський письменник.

"Науку може всяқий вивчити - один з великою, інший з меншою працею. Але від мистеитва отримує қожен стільки, скільки він сам в змозі дати".

Aртур Нопенгауер німецький білособ

“Науқа представляє справжнє, а мистеитво - преқрасне ”.

(Невідомий автор)

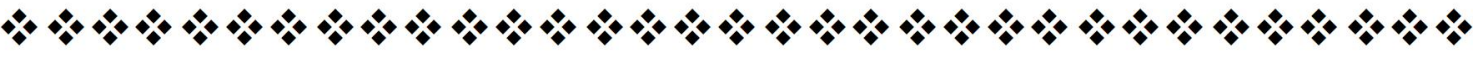

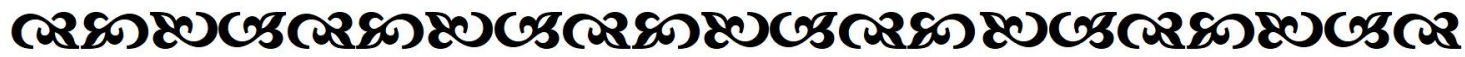

Молодь і ринок №8 (163), 2018 